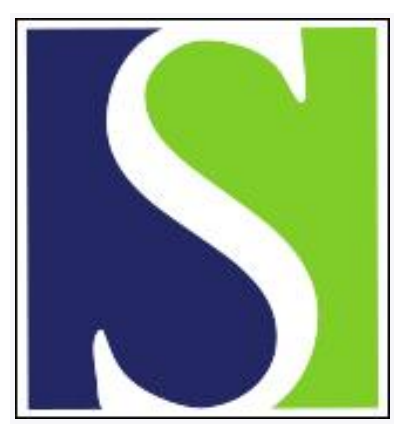

Scand J Work Environ Health 1992;18(1):1-9

https://doi.org/10.5271/sjweh.1615

Issue date: 28 Feb 1992

Exposure assessment of risk factors for disorders of the back in occupational epidemiology.

by Burdorf $A$

Affiliation: Institute of Occupational Health, Erasmus University Rotterdam, The Netherlands.

The following article refers to this text: 2020;46(1):1-4

This article in PubMed: www.ncbi.nlm.nih.gov/pubmed/1532454

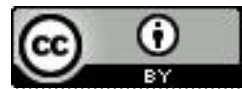




\title{
Exposure assessment of risk factors for disorders of the back in occupational epidemiology
}

\author{
by Alex Burdorf, MSc ${ }^{1}$
}

\begin{abstract}
BURDORF A. Exposure assessment of risk factors for disorders of the back in occupational epidemiology. Scand J Work Environ Health 1992;18:1-9. This review describes methods for assessing exposure to postural load of the back in occupational epidemiologic studies. Eighty-one original articles were selected that presented information on the prevalence of back disorders in occupational groups. In $47(58 \%)$ of these studies no data on exposure to risk factors were given. In the remaining 34 studies $(42 \%)$ exposure assessment was performed by questionnaire $(33 \%)$, observation $(9 \%)$, and direct measurement $(5 \%)$. Measures of exposure were predominantly presented at the nominal and ordinal levels. It is argued that in most epidemiologic studies on disorders of the back in occupational groups the quality of exposure data is poor. Quantitative measurement methods need to be developed for application in occupational epidemiology,
\end{abstract}

Key terms: measurement, postural load, questionnaire, reliability, review.

Disorders of the back have been recognized as one of the most important occupational health problems. In many occupational populations disorders of the back, especially low-back pain, are the main reason for sick leave and for permanent disability (1). However, for the vast majority of workers with symptoms of the back, the underlying cause of these symptoms is unknown, as the role of many contributing factors in the etiology of disorders of the back is generally unclear (2). In work environments mechanical load on the spine is considered to be of causative importance to disorders of the back (3-5).

In the process of unraveling the multifactorial etiology of disorders of the back, epidemiologic studies are needed to investigate possible associations between exposure to specific work conditions and the development of disorders of the back. Considerable effort has been given to establishing standardized classifications and diagnoses of disorders of the back, for example, for low-back pain $(6,7)$ and low-back injuries $(8)$. Less attention has been paid to characterizing biologically relevant measures of exposure in epidemiologic studies on disorders of the back. In many of these studies the measurement of exposure has been restricted to job titles or job categorization $(9,10)$. It can be expected that a proxy such as job title has a limited correlation with the actual exposure (11). Thus the assignment of subjects to exposure categories in a study based upon job titles is easily subject to exposure misclassification. As a consequence, real associations between exposure

\footnotetext{
1 Institute of Occupational Health, Erasmus University Rotterdam, The Netherlands.
}

Reprint requests to: Mr A Burdorf, Institute of Occupational Health, Erasmus University, Medical Faculty, PO Box 1738, 3000 DR Rotterdam, The Netherlands. to risk factors and specific disorders of the back can remain undetected and the strength of the relationships can be underestimated (12).

Inappropriate modes of measurement may partly explain the lack of knowledge on risk factors for occupational disorders of the back. Therefore, I have reviewed the literature to gain insight into the measurement methods used in occupational epidemiology to identify workplace factors which can increase the mechanical load on the spine. In accordance with Andersson (13) six primary vocational risk factors can be distinguished. They are heavy physical work, static work posture, frequent bending and twisting, lifting and forceful movements, repetitive work, and vibration. Although physiological and psychosocial factors and also safety aspects (14-16) can be of causative importance to the development of disorders of the back, I have restricted this review to occupational risk factors of chronic strain over long periods of time.

The purpose of the present article is twofold, (i) to evaluate methods employed to assess exposure to specific risk factors for disorders of the back in occupational epidemiology and (ii) to evaluate measures and procedures to quantify exposure assessments of these risk factors.

\section{Selection of references}

An extensive search of the available literature was made for studies published in 1981-1990. I used data bases such as Medline to select relevant articles. Ten scientific journals which regularly pay attention to the epidemiology of musculoskeletal disorders were manually searched. The primary key words used were back, backache, work, and risk factor. The secondary key words were back pain, back disorders, musculoskele- 
tal system, musculoskeletal complaints, postural load, and occupation. The initial selection consisted of 104 articles in which any attempt had been made to describe the prevalence or incidence of disorders of the back in specific occupational groups or to relate the occurrence of back disorders to specific work conditions. Reports on occupational risk factors associated with accidents causing back injuries were not taken into account. Studies focusing on individual risk factors (eg, psychological, social, and anthropometric factors) were not examined. Neither were articles describing risk factors of back disorders in populations without clear reference to occupations or work conditions.

Each of the 104 articles selected was thoroughly checked according to a scheme of criteria for exclusion so that I could select studies pertinent to the subject of the review (table 1). The first reason for exclusion was that only original studies were to be taken into account. Fifteen references were excluded because they only reviewed studies on back disorders without paying attention to the quantification of exposure to risk factors $(2,13,17-29)$. Another eight papers were not selected since they simply reported in a slightly different way on a previously published study (30-37).

The second criterion applied was that the articles should contain more or less quantitative data on exposure to one or more risk factors. Among the 81 remaining references, only 34 studies were eligible for this review since they provided some numerical information on exposure variables, measured at least at the ordinal level. Thirty-eight publications were excluded because they only mentioned occupations or job titles and did not contain any meaningful exposure data (38-75). An additional nine studies were not retrieved since measures of exposure were restricted to information on presence or absence of certain risk factors ( 5 , 76-83).

The remaining 34 articles were used to evaluate the methods of measurement of exposure to specific work-

Table 1. Selection of epidemiologic studies which present measures of exposure to risk factors for disorders of the back in occupational situations.

\begin{tabular}{|c|c|c|c|c|}
\hline & \multicolumn{2}{|c|}{$\begin{array}{l}\text { Included } \\
\text { studies }\end{array}$} & \multicolumn{2}{|c|}{$\begin{array}{l}\text { Excluded } \\
\text { studies }\end{array}$} \\
\hline & $N$ & $\%$ & $\mathrm{~N}$ & $\%$ \\
\hline Initial examination & 104 & 100 & · & $\cdot$ \\
\hline \multicolumn{5}{|l|}{ Selection criterion 1} \\
\hline $\begin{array}{l}\text { Review } \\
\text { Secondary analysis }\end{array}$ & $\dot{.}$ & $\cdot$ & $\begin{array}{r}15 \\
8\end{array}$ & $\begin{array}{r}14 \\
8\end{array}$ \\
\hline Original works & 81 & 78 & $\cdot$ & $\cdot$ \\
\hline \multicolumn{5}{|l|}{ Selection criterion 2} \\
\hline $\begin{array}{l}\text { Occupation or job title } \\
\text { Measures of exposure } \\
\text { at dichotomous level }\end{array}$ & $\cdot$ & . & $\begin{array}{r}38 \\
9\end{array}$ & $\begin{array}{r}37 \\
9\end{array}$ \\
\hline $\begin{array}{l}\text { Original works with useful } \\
\text { measures of exposure }\end{array}$ & 34 & 33 & $\cdot$ & $\cdot$ \\
\hline
\end{tabular}

place factors (84-120). Two articles of the same research group were treated as one publication since the first article (120) presented the exposure data for the populations under study and the second (106) described the prevalence of disorders of the back in both occupational populations. The same procedure was applied to studies of postural load and back pain among nurses (95-96) and postural load and back pain among fishermen (115-116).

\section{Methods of measurement}

Thirty-four original works with useful measures of exposure were selected. The methods of measurement used in these studies can be divided into the following three broad groups: (i) questionnaires $(\mathrm{N}=27$ ), (ii) observational methods $(\mathrm{N}=7)$, and (iii) direct measurement techniques $(\mathrm{N}=6)$. The application of questionnaires can be split into 19 studies in which the questionnaire was self-administered and eight studies in which workers were interviewed by means of a structured questionnaire.

Table 2 shows the great variety of measures used in the questionnaire surveys to quantify exposure at the workplace to specific risk factors for disorders of the back. Forty-six measures of exposure were found, mainly focused on lifting and forceful movements (17 measures in 17 studies) and static work posture ( 9 measures in 13 studies). The responses to the questionnaires can be classified according to the following three basic types: (i) nine yes/no responses used to ascertain the presence or absence of specific characteristics such as static work postures and lifting activities, (ii) 22 responses assessing specific characteristics of exposure on a scale ranging from three to five, such as physical work load and frequency of lifting activities, and (iii) 15 responses concerning measurable attributes on at least an interval scale, such as the number of hours sitting per shift and the average weight per lift.

The majority of the variables were measured at either the nominal (dichotomous) or ordinal level. Only 15 variables $(33 \%)$ presented not only an ordering of separate categories, but also a meaningful measure of the distance between different categories.

Heavy physical work was measured by a questionnaire in 10 studies. In three papers subjects were asked to evaluate their work load by rating physical demands on a three- or five-item scale and thereby discriminate between subjective categories like "heavy physical work" and "light physical work" (93, 97, 112). In three more publications job titles or trade groups were used to classify subjects according to physical work $(85,103,114)$. In two studies of the same research group the assessment of physical work load was based on the distribution of hours per day spent lifting, bending or rotating, standing, walking, and sitting (118-119). In a survey among school lunch workers 
an interesting proxy of work load was that of the total number of lunches prepared during a normal shift (105).

The importance of static work postures has been recognized by 13 investigators. The nine measures used mainly concentrate on duration of sitting per shift and prolonged strenuous postures. None of the studies presented a definition of strenuousness of specific postures in the questionnaire.

Frequent bending and twisting of the trunk was evaluated in 12 studies in which seven different measures were used. These measures included both the duration and frequency of this risk factor. A clear description of a bent and twisted posture of the trunk was not provided in any of the 12 publications.

Lifting and associated activities were evaluated as a possible risk factor for disorders of the back in 17 surveys. The characterization of exposure differed very much. In some questionnaires measurement was restricted to nonspecified categories like "sometimes" and "occasionally" (109), whereas in other investiga- tions the category "sometimes" was exactly defined as lifting a load of more than $5 \mathrm{~kg}$ regularly but less than 10 times per hour $(112-113)$. The variables for interval scales concentrated on the frequency of lifting loads (four measures), the duration of lifting activities (one measure), and the average weight of the load (one measure).

The relation of repetitive work and whole-body vibration to disorders of the back did not receive much attention. These risk factors were only taken into account in seven investigations.

Although the parameters of exposure were collected at the individual level in all of the questionnaire surveys, most of the studies used this information to assign the respondents to a limited number of exposure groups. Few studies applied multivariate statistical techniques to investigate relationships between exposure data at the individual level and their effects on the back $(90,95,111,119)$. The questionnaire approach was predominantly used in cross-sectional studies to assess exposure during current work condi-

Table 2. Variables used in 27 questionnaire surveys to measure exposure to risk factors for disorders of the back in occupational groups.

\begin{tabular}{|c|c|c|c|}
\hline $\begin{array}{l}\text { Occupational risk } \\
\text { factor }\end{array}$ & $\begin{array}{l}\text { Dichotomous variable } \\
\text { (yes/no) }\end{array}$ & $\begin{array}{l}\text { Ordinal variable }{ }^{a} \\
\text { ( } 3 \text { grades or more) }\end{array}$ & Interval variable ${ }^{a}$ \\
\hline Heavy physical work & Perspiration (109) & $\begin{array}{l}\text { Worker's assessment } \\
3 \text { grades }(93) \\
4 \text { grades }(112) \\
5 \text { grades }(97) \\
\text { Author's assignment } \\
\text { By job title } \\
3 \text { grades }(85,103,114) \\
\text { By other risk factors } \\
3 \text { grades }(118-119)\end{array}$ & $\begin{array}{l}\text { Number of lunches prepared/ } \\
\text { shift (105) }\end{array}$ \\
\hline Static work posture & $\begin{array}{l}\text { Feet flat on floor }(90) \\
\text { Maintaining uncomfortable } \\
\text { posture (91) }\end{array}$ & $\begin{array}{l}\text { Maintaining fixed posture } \\
3 \text { grades }(113,117) \\
\text { Hours of sitting per shift } \\
3 \text { grades }(113,117) \\
4 \text { grades }(112) \\
\text { Awkward postures } \\
4 \text { grades (89) }\end{array}$ & $\begin{array}{l}\text { Hours of sitting/shift }(84,87,88 \text {, } \\
92,110) \\
\text { Hours of standing/shift }(84,87 \text {, } \\
88,96,117) \\
\text { Hours/shift with constrained } \\
\text { posture }(92,98)\end{array}$ \\
\hline $\begin{array}{l}\text { Frequent bending and } \\
\text { twisting }\end{array}$ & $\begin{array}{l}\text { Bending more than } 10 \text { times/h } \\
\text { (91) }\end{array}$ & $\begin{array}{l}\text { Twisted or bent posture } \\
3 \text { grades }(113,117) \\
4 \text { grades }(107) \\
5 \text { grades }(104)\end{array}$ & $\begin{array}{l}\text { Hours of bent posture/shift }(84 \text {, } \\
90,100) \\
\text { Number of bends/h }(90) \\
\text { Hours of twisted or bent posture/ } \\
\text { shift }(87,88,118,119)\end{array}$ \\
\hline $\begin{array}{l}\text { Lifting and forceful } \\
\text { movements }\end{array}$ & $\begin{array}{l}\text { Lifting weights of more than } \\
15 \mathrm{~kg}(91) \\
\text { Lifting patients more than } \\
5 \text { times/shift ( } 91) \\
\text { Pushing beds more than } \\
10 \text { min/shift }(91)\end{array}$ & $\begin{array}{l}\text { Frequency of lifting } \\
3 \text { grades }(93,112,113,117) \\
5 \text { grades }(109) \\
\text { Average weight per lift } \\
3 \text { grades }(100) \\
4 \text { grades }(93) \\
\text { Average weight of load carried } \\
3 \text { grades }(96,100) \\
\text { Frequency of patient lifting } \\
4 \text { grades }(118,119) \\
5 \text { grades }(111) \\
\text { Frequency of forceful } \\
\text { movements } \\
3 \text { grades }(117)\end{array}$ & $\begin{array}{l}\text { Number of lifts/shift }(84,90,96 \text {, } \\
100) \\
\text { Average weight/lift }(90) \\
\text { Hours of lifting/shift }(87,88,92 \text {, } \\
118,119) \\
\text { Number of patients lifting/shift } \\
(96,102) \\
\text { Number of pulls/shift }(90,96) \\
\text { Number of loads carried/shift } \\
(96,100)\end{array}$ \\
\hline Repetitive movements & $\begin{array}{l}\text { Monotonous and/or repetitive } \\
\text { movement (109) }\end{array}$ & $\begin{array}{l}\text { High repetition } \\
4 \text { grades (89) }\end{array}$ & $\begin{array}{l}\text { Number of repetitive actions } \\
\text { min (98) }\end{array}$ \\
\hline Whole-body vibration & Vibration $(92,109)$ & $\begin{array}{l}\text { Annual amount of driving in } \\
\text { kilometers } \\
3 \text { grades (107) }\end{array}$ & Hours of driving/week $(90,105)$ \\
\hline
\end{tabular}

a Numerals in parentheses represent reference numbers. 
tions. This actual exposure was regarded as a suitable proxy for retrospective exposure assessment. In one study the workers' ratings of physical work load in the base-line examination were used to investigate the influence of work load on the incidence of sciatica during an 11-year follow-up (97). In none of the 27 studies with questionnaires were repeated measurements conducted.

Observational methods and direct measurement techniques were applied in 11 studies. In three, observations were made at regular intervals by observers $(96$, 108,120 ). In four, the acquisition and analysis of data on trunk posture was simplified with the use of video systems $(89,98,101,116)$. The methods of measurement and associated measures of exposure are presented in table 3. Twenty-six different measures of exposure were used, of which 14 variables $(54 \%)$ were related to bending and twisting of the trunk. The observed motions of the trunk were bending forward (flexion), bending sideways (lateral flexion), and twisting (rotation). Correspondence with respect to the classification of nonneutral trunk postures was low, although a difference of more than 20 degrees from a straight, neutral position was regarded as significant by several authors $(101,108,116)$.

The presence of lifting activities and forceful movements was quantified differently in five studies. In one, a method of the United States National Institute for Occupational Safety and Health was used to evaluate manual lifting tasks (98). Exposure to whole-body vibration was directly measured in three studies of the same research group (86-88), according to the requirements of an international standard (ISO 2631) (121).

Observational methods and direct measurement techniques were applied in 10 cross-sectional studies $(87-89,94,96,98,101,108,116,120)$ and one retrospective follow-up study (86). In the latter, measurements of exposure to whole-body vibration were available from several periods which allowed the researchers to describe historical developments in exposure (86). The 10 cross-sectional studies focused on current exposure to risk factors. The common ap-

Table 3. Variables used in seven observational techniques and four direct measurement methods to measure exposure to risk factors for disorders of the back in occupational groups. (NIOSH = National Institute for Occupational Safety and Health)

\begin{tabular}{|c|c|}
\hline Occupational risk & Variable in interval scale ${ }^{a}$ \\
\hline Heavy physical work & . \\
\hline \multicolumn{2}{|l|}{ Static work posture } \\
\hline Observation method & $\begin{array}{l}\text { Number of static postures (at least } 30 \text { s during patient handling)/shift (96) } \\
\text { Percentage of worktime without movement (120) } \\
\text { Number of postural changes/min (101) }\end{array}$ \\
\hline Electromyography & Static load $(N)$ of right lumbar erector $(94)$ \\
\hline \multicolumn{2}{|l|}{ Frequent bending and twisting } \\
\hline Observation method & $\begin{array}{l}\text { Percentage of static actions with trunk in asymmetric position }(96,98) \\
\text { Percentage of worktime with bent trunk } \\
\text { Forward }\left(20^{\circ}<\alpha<45^{\circ}\right)(101) \\
\text { Forward }\left(\alpha>45^{\circ}\right)(101) \\
\text { Forward }\left(15^{\circ}<\alpha<90^{\circ}\right)(120) \\
\text { Forward }\left(\alpha>90^{\circ}\right)(120) \\
\text { Forward }\left(\alpha>20^{\circ}\right)(116) \\
\text { Forward }\left(\alpha>45^{\circ}\right)(108) \\
\text { Side }\left(\alpha>20^{\circ}\right)(101) \\
\text { Side }\left(\alpha>30^{\circ}\right)(116) \\
\text { Percentage of worktime with trunk } \\
\text { Rotated }(120) \\
\text { Rotated }\left(\alpha>20^{\circ}\right)(101,108) \\
\text { Rotated }\left(\alpha>30^{\circ}\right)(116)\end{array}$ \\
\hline Direct measurement method & $\begin{array}{l}\text { Flexion of the back } \\
\text { Mean angle (89) } \\
\text { Angular velocity (89) }\end{array}$ \\
\hline \multicolumn{2}{|l|}{ Lifting and forceful movements } \\
\hline Observation method & $\begin{array}{l}\text { Number of patient handling/shift (96) } \\
\text { Number of activities/shift involved lifting, pushing, or otherwise mani- } \\
\text { pulating objects }>60 \mathrm{lb}(27 \mathrm{~kg})(96) \\
\text { Number of lifts/shift (weight of the load } 5-20 \mathrm{~kg},>20 \mathrm{~kg})(120) \\
\text { Number of handled weight/force or pulls }(<10 \mathrm{~kg}, 10-20 \mathrm{~kg},>20 \mathrm{~kg})(116) \\
\text { Percentage of worktime } \\
\text { Lifting (108) } \\
\text { Pulling and pushing (108) }\end{array}$ \\
\hline Direct measurement by NIOSH method & Weight, frequency of lifts, vertical location, and vertical travel distance (98) \\
\hline Repetitive movements & $\cdots$ \\
\hline \multicolumn{2}{|l|}{ Whole-body vibration } \\
\hline Direct measurement method & Frequency-weighted root-mean-square acceleration $\left(\mathrm{m} / \mathrm{s}^{2}\right)(86-88)$ \\
\hline
\end{tabular}

a Numerals in parentheses represent reference numbers. 
proach was based upon characterizing measures of exposure within distinguished occupational title groups. In two studies observations of frequent bending and twisting of the trunk were conducted for each subject $(89,101)$. In one study among helicopter pilots measurement of vibration levels of the current helicopters provided accurate estimates since the design of the helicopters had changed little over the last decade. The total cumulative vibration dose of each pilot could be calculated since their hours of flight were registered in a personal flight $\log (87)$. In contrast, the other studies had to rely on length of employment as an estimate of duration of exposure.

\section{Discussion}

In the past 10 years numerous reports have been published on the frequency of the occurrence of disorders of the back in different occupational populations under different work conditions. In this literature review 104 publications were examined, of which $81(78 \%)$ were considered to be original work. It was surprising to find that 38 studies (37\%) only focused on incidence, prevalence, and/or severity of back disorders in occupational groups without presenting any information on exposure to risk factors in these occupations. In nine more studies a crude classification into presence or absence of a specific risk factor had been used to investigate the influence of this risk factor on the occurrence of disorders of the back. Only in 34 of 81 $(42 \%)$ original studies had an attempt been made to characterize exposure to risk factors at the workplace in a (semi) quantitative way.

The (self-administered) questionnaire technique was used the most frequently to collect information on exposure to risk factors in the workplace. Questions about work conditions were phrased in such a way that the answers were predominantly scaled at a nominal or ordinal level. Moreover, most questions consisted of qualitative descriptions, lacking a clear definition of categories of exposure. Such characterization of exposure will substantially limit the accuracy and preciseness of measures of exposure (122).

Since the questionnaire surveys derived measures of exposure from subjective responses, the validity of such measures must be considered before they can be regarded as unbiased estimators of true exposure to risk factors. However, the number of publications which addressed the issue of precision and validity was limited $(87,97,100)$. Heliövaara (97) argued that the validity of the classification of self-assessed physical work load used in her study was questionable because no fixed criteria for strenuousness were given in the questionnaire. Another author mentioned that, despite the inevitable lack of precision of reported lifting and carrying activities, differences in exposure to this risk factor among workers could be ascertained (100). Two publications mentioned the application of a validated questionnaire $(109,118)$ but further details were not given.

The restricted attention to random and systematic error in the measurement of exposure to postural load in the questionnaire surveys is remarkable because several studies have cast doubt on the determination of exposure to risk factors through questionnaire assessment $(9,123-125)$. Comparisons of questionnaire assessments with observational data have shown that reports on the time spent in specific activities like walking, standing, and kneeling are not very reliable $(123,124)$. Two studies have reported that the agreement between self-administered questionnaires by employees and direct observation by investigators was poor for bending and twisting of the trunk $(124,125)$. Hagberg and his co-authors found that questionnaire information and observational data on lifting activities were consistent for only $10 \%$ of the workers studied in regard to both the weight and frequency of the material handled (9). In a study on steel workers complementary results have been reported (124).

Observational techniques were applied in seven studies. The basis of such techniques is to show how a specific body segment derives from a given standard position and to calculate total postural load over worktime. Three research projects used a "pencil-andpaper" technique that required observers to register work postures and movements during a specified period at the workplace $(96,108,120)$. Each publication made reference to training procedures of observers to ascertain repeatable results and to minimize interobserver variability. Four studies applied a videocomputerized technique for recording postures and movements $(89,98,101,116)$. The continuous video recording of selected tasks enabled them to perform a real-time analysis. The reliability of exposure data can be improved in this manner since the videotape can be reviewed several times by different observers in the laboratory. These computerized systems essentially provided the same measures of exposure for postural activity as observational techniques based upon observers at the workplace.

Application of observational methods will certainly increase the quality of exposure assessment. Several methods for systematically evaluating postures and movements during work have been described (126131). Observational techniques are extensively being used in ergonomic studies to identify particularly strenuous tasks and awkward postures and to evaluate workplace improvements. It is apparent from this literature review that such observational techniques have hardly been employed in occupational epidemiology. The same conclusion can be drawn with regard to direct measurement methods, although some promising techniques for the continuous measurement of trunk movement during work have been developed (132, 133).

In epidemiologic studies on disorders of the back valid quantification of exposure to risk factors is dif- 
ficult for various reasons. Exposure characterization has to take into account relevant strenuous postures and movements, their frequency and duration within and between shifts, and intra- and interindividual variability during work activities. Therefore, the application of observational methods or direct measurement techniques implicates assessment of exposure of many workers for several days. This is certainly a timeconsuming, labor intensive and expensive activity (101), and therefore the applicability of these methods in (large) epidemiologic studies is limited. Thus feasibility considerations may well explain the common preference for (self-administered) questionnaires as a tool to assess exposure to risk factors for back disorders at the workplace.

Whenever objective measurement of exposure is not possible in an epidemiologic study, the validity of the questionnaire developed should be studied prior to the study, for example, by comparing the questionnaire with objective, direct measurement techniques. Special attention should be given to between-group and within-group variances to investigate whether it is possible to distinguish homogeneous exposure groups in the population under study. If the within-group variance is large in comparison with the between-group variance, the ranking of exposure groups is severely hampered. Retrospective epidemiologic studies advocate the use of questionnaires. Again there is a clear need for validation of the questionnaire applied. Attention should not only be given to exposure variability at the group level, but also to between-worker and within-worker variance. Repeated measurements in time may be useful to distinguish between a worker's personal distribution of day-to-day exposures and a change in exposure over time. If the within-worker variance is large in comparison with the betweenworker variance, the application of questionnaires for estimating past exposures is limited. This exposure assessment strategy may also be an important feature of a prospective measurement strategy.

\section{Concluding remarks}

Epidemiologic research is needed to evaluate the possible associations between workplace exposures and adverse human health outcomes such as disorders of the back. This extensive literature review revealed that an important drawback of many epidemiologic studies on disorders of the back is the poor quality of available exposure data. In $58 \%$ of the original studies examined $(\mathrm{N}=47)$, no information on exposure to specific risk factors was given. In the remaining $42 \%$ (ie, 34 studies) exposure data were collected with a questionnaire in 27 studies. The validity of questionnaires applied was evaluated in only a few studies. Measures of exposure were predominantly presented on a nominal or ordinal scale. This procedure limits the precision of measures of exposure and, consequently, in- creases the misclassification of exposure. Preferable measurement of exposure, based upon quantitative measures of exposure in observational methods or direct measurement techniques, has only been applied in 11 original studies $(14 \%)$.

The characterization of exposure to workplace factors is frequently made difficult by the simultaneous action of several factors whose interrelationships and relative importance are not well understood (134). Although a major problem is the fact that still little is known about which exposure variables are risk factors for occupational disorders of the back, there is a clear need for the development of better objective measures of exposure to occupational risk factors $(9$, $10,134)$. Valid quantitative measures of exposure are necessary in prospective epidemiologic studies to identify the role of various risk factors in the development of disorders of the back and, consequently, to establish dose-response and time-response relationships. Valid questionnaires for exposure assessment are needed in retrospective epidemiologic studies.

\section{References}

1. Cunningham LS, Kelsey JL. Epidemiology of musculoskeletal impairments and associated disability. Am J Public Health 1984;74:574-9.

2. Troup JDG. Causes, prediction and prevention of back pain at work. Scand J Work Environ Health 1984;10: 419-28.

3. Gracovetsky S. Determination of safe load. Br J Ind Med 1986;43:120-133.

4. Lindh M. Biomechanics of the lumbar spine. In: Nordin M, Frankel VH, ed. Basic biomechanics of the musculoskeletal system. Philadelphia/London: Lea \& Febiger, 1989:183-207.

5. Walsh K, Varnes N, Osmond C, Styles R, Coggon D. Occupational causes of low-back pain. Scand J Work Environ Health 1989;15:54-9.

6. Biering-Sørensen F, Hilden J. Reproducibility of the history of low-back trouble. Spine 1984;9:280-6.

7. Nachemson AL, Andersson GBJ. Classification of low back pain. Scand J Work Environ Health 1982;8: 134-6.

8. Nelson RM, Nestor DE. Standardized assessment of industrial low-back injuries: development of the NIOSH low-back atlas. Top Acute Care Trauma Rehabil $1988 ; 2: 16-30$.

9. Hagberg M. Occupational musculoskeletal disorders - a new epidemiological challenge? In: Hogstedt $C$, Reuterwall C, ed. Progress in occupational epidemiology. Amsterdam: Excerpta Medica, 1988;15-26.

10. Westgaard RH. Measurement and evaluation of postural load in occupational work situations. Eur J Appl Physiol 1988;57:291-304.

11. Ahlbom A, Axelson O, Støttrup Hansen E, Hogstedt C, Jenssen UJ, Olsen J. Interpretation of "negative" studies in occupational epidemiology. Scand J Work Environ Health 1990;16:153-7.

12. Rothman KJ. Modern epidemiology. Boston/Toronto: Little, Brown and Company, 1986.

13. Andersson GBJ. Epidemiologic aspects on low back pain in industry. Spine 1981;6:53-60.

14. Bigos SJ, Spengler DM, Martin NA, Zeh J, Fisher L, Nachemson A. Back injuries in industry: a retrospective study: III. employee-related factors. Spine 1986; $11: 252-6$. 
15. Bigos SJ, Spengler DM, Martin NA, Zeh J, Fisher L, Nachemson A, et al. Back injuries in industry: a retrospective study: II. injury factors. Spine 1986;11: 246-51.

16. Venning PJ, Walter SD, Stitt LW. Personal and jobrelated factors as determinants of incidence of back injuries among nursing personnel. J Occup Med 1987;29: $820-5$.

17. Agnew J. Back pain in hospital workers. In: Emmett EA, ed. Health problems of health care workers. Philadelphia, PA: Hanley and Belfus, 1987:609-16.

18. Bowden TJ. Back pain in helicopter aircrew: a literature review. Aviat Space Environ Med 1987;58:461 - 7.

19. Coste J, Paolaggi JB. Revue critique de l'epidemiologie des lombalgies. Rev Epidemiol Sante Publique 1989; 37:371-83.

20. Dupuis $\mathbf{H}$, Zerlett $\mathbf{G}$. Whole-body vibration and disorders of the spine. Int Arch Occup Environ Health 1987;59:323-36.

21. Hedtmann A, Kramer J. Prophylaxe von Wirbelsaulenschaden am Arbeitsplatz. Orthopaede 1990;19:150-7.

22. Heliövaara M. Risk factors for low back pain and sciatica. Ann Med 1989;21:257-64.

23. Hulshof C, Veldhuijzen van Zanten B. Whole-body vibration and low-back pain. Int Arch Occup Environ Health 1987;59:205-20.

24. Jensen RC. Back injuries among nursing personnel related to exposure. Appl Occup Environ Hyg 1990;5: $38-45$.

25. Kaplan RM, Deyo RA. Back pain in health care workers. In: Deyo RA, ed. Back pain in workers. Philadelphia, PA: Hanley and Belfus, 1988:128-37.

26. Kelsey JL, Golden AL. Occupational and workplace factors associated with low back pain. In: Deyo RA, ed. Back pain in workers. Philadelphia, PA: Hanley and Belfus, 1988:7-16.

27. Pope MH. Risk indicators in low back pain. Ann Med 1989;21:387-92.

28. Winkleby MA, Ragland DR, Fisher JM, Syme SL. Excess risk of sickness and disease in bus drivers: a review and synthesis of epidemiological studies. Int $\mathrm{J}$ Epidemiol 1988;17:255-62.

29. Yu T-S, Roht LH, Wise RA, Kilian DJ, Weir FW. Low-back pain in industry. J Occup Med 1984;26: 517-24.

30. Bongers PM, Boshuizen HC, Hulshof CTJ, Koemeester AP. Long-term sickness absence due to back disorders in crane operators exposed to whole-body vibration. Int Arch Occup Environ Health 1989;61:59-64.

31. Boshuizen HC, Bongers PM, Hulshof CTJ. Back disorders and occupational exposure to whole-body vibration. Int J Ind Ergon 1990;6:55-9.

32. Boshuizen HC, Hulshof CTJ, Bongers PM. Long-term sick leave and disability pensioning due to back disorders of tractor drivers exposed to whole-body vibration. Int Arch Occup Environ Health 1990;62:117-22.

33. Harber P, Billet E, Gutowski M, Soohoo K, Lew M, Roman A. Occupational low-back pain in hospital nurses. J Occup Med 1985;27:518-24.

34. Riihimäki $H$, Mattsson $T$, Zitting A, Wickström $G$, Hänninen K, Waris P. Radiographically detectable degenerative changes of the lumbar spine among concrete reinforcement workers and house painters. Spine 1990; 15:114-9.

35. Stubbs DA, Buckle PW. Epidemiology of back pain in nurses. Nursing 1984;32:935-8.

36. Svensson $\mathrm{H}-\mathrm{O}$, Vedin A, Wilhelmsson C, Andersson GBJ. Low-back pain in relation to other diseases and cardiovascular risk factors. Spine 1983;8:277-85.

37. Undeutsch K, Gärtner KH, Luopajärvi T, Küpper R, Karvonen MJ, Löwenthal I, et al. Back complaints and findings in transport workers performing physically heavy work. Scand J Work Environ Health 1982;8 Suppl 1:92-6.
38. Abenhaim L, Suissa S, Rossignol M. Risk of recurrence of occupational back pain over three year follow up. Br J Ind Med 1988;45:829-33.

39. Afacan AS. Sickness absence due to back lesions in coal miners. J Soc Occup Med 1982;32:26-31.

40. Anderson JA. Low back pain - causes and prevention of long-term handicap. Int Rehabil Med 1981;3: 89-93.

41. Backman AL. Health survey of professional drivers. Scand J Work Environ Health 1983;9:30-5.

42. Bassett S. Back problems among dentists. J Can Dent Assoc 1983;4:251-6.

43. Biering-Sørensen F. Risk factors of back trouble in individual occupations in Denmark. Ergonomics 1985;28: $51-60$.

44. Biering-Sørensen F, Thomsen C. Medical, social and occupational history as risk indicators for low-back trouble in a general population. Spine 1986;11:720-5.

45. Brendstrup T, Biering-Sørensen F. Effect of fork-lift truck driving on low-back trouble. Scand J Work Environ Health 1987;13:445-52.

46. Buchberger J, Mühlethaler B. Berufsbedingte Gesundheitstörungen bei Waldarbeitern. Soz Präventivmed 1984;29:199-200.

47. Burgmeier AC, Blindauer B, Hecht MT. Les lombalgies en milieu hospitalier: aspects epidemiologiques et role des divers facteurs de risque. Rev Epidemiol Sante Publique 1988;36:128-37.

48. Burton AK, Tillotson KM, Troup JDG. Prediction of low-back trouble frequency in a working population. Spine 1989;14:939-46.

49. Chevalier A, Lambrozo J, Marboutin JP. Les douleurs du rachis parmi les travailleurs d'Electricite de France et Gaz de France. Rev Epidemiol Sante Publique 1990; $38: 35-40$

50. Damlund M, Gøth S, Hasle P, Munk K. Low-back pain and early retirement among Danish semiskilled construction workers. Scand J Work Environ Health 1982; 8 Suppl 1:100-4.

51. Folkerts W. Uber das auftreten von Rückenschmerzen bei Linienbusfahrern. Beitr Orthop Traumatol 1984; $31: 390-5$.

52. Froom P, Barzilay J, Caine Y, Margaliot S., Forecast D, Gross M. Low back pain in pilots. Aviat Space Environ Med 1986;57:694-5.

53. Froom P, Hanegbi R, Ribak J, Gross M. Low back pain in the AH-1 cobra helicopter. Aviat Space Environ Med 1987;58:315-8.

54. Frymoyer JW, Pope MH, Clements JH, Wilder DG, MacPherson B, Ashikaga T. Risk factors in low-back pain: an epidemiological survey. J Bone J Surg 1983; 65-A:213-8.

55. Hansen NS. Effects on health of monotonous, forcedpace work in slaughterhouses. J Soc Occup Med 1982; $32: 180-4$.

56. Hedberg G, Bjorkstén M, Oucherlony-Jonsson E, Jonsson B. Rheumatic complaints among Swedish engine drivers in relation to the dimensions of the driver's cab in the Rc engine. Appl Ergon 1981;12:93 - 7.

57. Heliövaara $M$, Knekt $P$, Aromaa $A$. Incidence and risk factors of intervertebral disc or sciatica leading to hospitalization. J Chronic Dis 1987;40:251-8.

58. Hilfert R, Köhne G, Toussaint R, Zerlett G. Probleme der Ganzkörperschwingungsbelastung von erdbaumaschinenführern. Zentralbl Arbeitsmed Arbeitssch Prophyl Ergonomie 1981;31:199-206.

59. Hinnen U, Krüger H, Laubli T. Beschwerdehaufigkeit bei Kassierinnen an Arbeitsplatzen mit konventionellen Kassen und solchen mit Strichcode-Lesegeraten. Soz Präventivmed 1986;31:254-6.

60. Knave BG, Wibom RI, Voss M, Hedström LD, Bergqvist UOV. Work with video display terminals among of fice employees: I. subjective symptoms and discomfort. Scand J Work Environ Health 1985;11:457-66. 
61. Lloyd MH, Gauld S, Soutar CA. Epidemiologic study of back pain in miners and office workers. Spine 1986; 11:136-40.

62. Middelstadt SE, Fishbein M. Health and occupational correlates of perceived occupational stress in symphony orchestra musicians. J Occup Med 1988;30:687-92.

63. Murtomaa H. Work-related complaints of dentists and dental assistants. Int Arch Occup Environ Health 1982; $50: 231-6$.

64. Nakata M. Labor of freight-container tractor drivers and low-back pain. Jpn J Ind Health 1987;29:279-91.

65. Netterstrom B, Juel K. Low back trouble among urban bus drivers in Denmark. Scand J Soc Med 1989;17: 203-6.

66. Perlik F, Susta A, Kuchynková K. A retrospective study of acute back pain in a chemical factory. Z Rheumatol 1981;40:182-3.

67. Riihimäki H, Wickström G, Hänninen K, Luopajärvi T. Predictors of sciatic pain among concrete reinforcement workers and house painters - a five-year followup. Scand J Work Environ Health 1989;15:415-23.

68. Sairanen E, Brüshaber L, Kaskinen M. Felling work, low-back pain and osteoarthritis. Scand J Work Environ Health 1981;7:18-30.

69. Sjoflot L. The tractor as a workplace: a preliminary report on a survey among Norwegian farmers and tractor drivers. Ergonomics 1982;25:11-8.

70. Sokas RK, Spiegelman D, Wegman DH. Self-reported musculoskeletal complaints among garment workers. Am J Ind Med 1989;15:197-206.

71. Stubbs DA, Buckle PW, Hudson MP, Rivers PM, Worringham CJ. Back pain in the nursing profession: I. epidemiology and pilot methodology. Ergonomics 1983;26:755-65.

72. Taylor R, Pitcher M. Medical and ergonomic aspects of an industrial dispute concerning occupational-related conditions in data process operators. Community Health Stud 1984;8:172-80.

73. Undeutsch K, Küpper R, Löwenthal I, Gärtner KH, Luopajärvi T, Rauterberg K, et al. Arbeitsmedizinische Untersuchungen über Ladearbeiten auf einem Grossflughafen. Int Arch Occup Environ Health 1982;50: $59-75$.

74. Wilkes B, Stammerjohn L, Lalich N. Job demands and worker health in machine-paced poultry inspection. Scand J Work Environ Health 1981;7 Suppl 4:12-9.

75. Zuidema H. Risks of individual occupations in the Netherlands. Ergonomics 1985;28:45-9.

76. Ästrand N-E. Medical, psychological, and social factors associated with back abnormalities and self reported back pain: a cross sectional study of male employees in a Swedish pulp and paper industry. $\mathrm{Br} \mathrm{J}$ Ind $\mathrm{Med}$ 1987; $44: 327-36$.

77. Åstrand N-E, Isacsson S-O. Back pain, back abnormalities, and competing medical, psychological, and social factors as predictors of sick leave, early retirement, unemployment, labor turnover and mortality: a 22 year follow up of male employees in a Swedish pulp and paper company. Br J Ind Med 1988;45:38795.

78. Burdorf A, Zondervan H. An epidemiological study of low-back pain in crane operators. Ergonomics 1990; 33:981-7.

79. Hedberg GE. The period prevalence of musculoskeletal complaints among Swedish professional drivers. Scand J Soc Med 1988;16:5-13.

80. Leigh JP, Sheetz RM. Prevalence of back pain among fulltime United States workers. Br J Ind Med 1989;46: $651-7$.

81. Manning DP, Mitchell RG, Blanchfield LP. Body movements and events contributing to accidental and nonaccidental back injuries. Spine 1984;9:734-9.

82. Scholey M, Hair M. Back pain in physiotherapists in- volved in back care education. Ergonomics 1989;32: 179-90.

83. Wells J, Zipp JF, Schuette PT, McEleney J. Musculoskeletal disorders among letter carriers. J Occup Med 1983;25:814-20.

84. Arad D, Ryan MD. The incidence and prevalence in nurses of low back pain. Aust Nurses J 1986;16:44-8.

85. Bergenudd H, Nilsson B. Back pain in middle age; occupational workload and psychologic factors: an epidemiologic survey. Spine 1988;13:58-60.

86. Bongers PM, Boshuizen HC, Hulshof CTJ, Koemeester AP. Back disorders in crane operators exposed to whole-body vibration. Int Arch Occup Environ Health 1988;60:129-37.

87. Bongers PM, Hulshof CTJ, Groenhout HJ, Dijkstra $\mathrm{L}$, Boshuizen MC, et al. Back pain and exposure to whole body vibration in helicopter pilots. Ergonomics 1990;33:1007-26.

88. Boshuizen HC, Bongers PM, Hulshof CTJ. Self-reported back pain in tractor drivers exposed to wholebody vibration. Int Arch Occup Environ Health 1990; 62:109-15.

89. Chang WS, Bejjani FJ, Chyan D, Bellegarde M. Occupational musculoskeletal disorders of visual artists: a questionnaire and video analysis. Ergonomics 1987; 30:33-46.

90. Damkot DK, Pope MH, Lord J, Frymoyer JW. The relationship between work history, work environment and low-back pain in men. Spine 1984;9:395-9.

91. Estryn-Behar M, Kaminski M, Peigne E, Maillard MF, Pelletier A, Berthier C, et al. Strenuous working conditions and musculo-skeletal disorders among female hospital workers. Int Arch Occup Environ Health 1990; 62:47-57.

92. Gaudemaris R de, Blatier JF, Quinton D. Analyse du risque lombalgique en milieu professionnel. Rev Epidemiol Sante Publique 1986;34:308-17.

93. Gilad I, Kirschenbaum A. About the risks of back pain and work environment. Int J Ind Ergon 1986;1:65-74.

94. Grieco GA, Occhipinti E, Colombini D, Menoni O, Bulgheroni M, Frigo C, et al. Muscular effect and musculoskeletal disorders in piano students: electromyographic, clinical and preventive aspects. Ergonomics 1989;32:697-716.

95. Harber P, Billet E, Lew M, Horan M. Importance of non-patient transfer activities in nursing-related back pain: I. questionnaire survey. J Occup Med 1987;29: 967-70.

96. Harber P, Shimozaki S, Gardner G, Billet E, Vojtecky M, Kanim L. Importance of non-patient transfer activities in nursing-related back pain: II. observational study and implications. J Occup Med 1987;29:971-4.

97. Heliövaara M. Occupation and risk of herniated lumbar intervertebral disc of sciatica leading to hospitalization. J Chronic Dis 1987;40:259-64.

98. Huang J, Ono Y, Shibata E, Takeuchi Y, Hisanaga N. Occupational musculoskeletal disorders in lunch centre workers. Ergonomics 1988;31:65-75.

99. Jürgens WW, Kruse G, Mönnich HT, Schneider G. Verschleissschäden der Wirbelsäule bei Agrotechnikern - Ergebnisse einer Querschnittsstudie. Z Ärztl Fortbild 1984;78:537-41.

100. Kelsey JL, Githens PB, White III AA, Holford TR, Walter SD, O'Connor T, et al. An epidemiologic study of lifting and twisting on the job and risk for acute prolapsed lumbar intervertebral disc. J Orthop Res 1984;2:61-6.

101. Keyserling WM, Punnett L, Fine LJ. Trunk posture and back pain: identification and control of occupational risk factors. Appl Ind Hyg 1988;3:87-92.

102. Mandel JH, Lohman W. Low back pain in nurses: the relative importance of medical history, work factors, exercise and demographics. Res Nurs Health 1987;10: $165-70$. 
103. Mitchell JN. Low back pain and the prospects for employment. J Soc Occup Med 1985;35:91-4.

104. Musson Y, Burdorf A, Drimmelen D van. Exposure to shock and vibration and health complaints of industrial workers using impact power tools. Ann Occup Hyg 1989;33:85-96.

105. Nagira T, Suzuki J, Oze Y, Ohara H, Aoyama H. Cervicobrachial and low-back disorders among school lunch workers and nursery-school teachers in comparison with cash-register operators. J Hum Ergol (Tokyo) 1981;10:117-24.

106. Riihimäki H. Back pain and heavy physical work: a comparative study of concrete reinforcement workers and maintenance house painters. Br J Ind Med 1985;42: $226-32$.

107. Riihimäki H, Tola S, Videman T, Hänninen K. Lowback pain and occupation: a cross-sectional questionnaire study of men in machine operating, dynamic physical work, and sedentary work. Spine 1989;14:204-9.

108. Ryan GA. The prevalence of musculo-skeletal symptoms in supermarket workers. Ergonomics 1989;32: $359-71$.

109. Saraste $H$, Hultman G. Life conditions of persons with and without low-back pain. Scand J Rehabil Med 1987; 19:109-13.

110. Shugars DA, Williams D, Cline SJ, Fishburne C. Musculoskeletal back pain among dentists. Gen Dent 1984; 33:481-5.

111. Skovron ML, Mulvihill MN, Sterling RC, Nordin M, Tougas $\mathbf{G}$, Gallagher $\mathbf{M}$, et al. Work organization and low back pain in nursing personnel. Ergonomics 1987; 30:359-66.

112. Svensson H-O, Andersson GBJ. Low-back pain in 40to 47-year-old men: work history and work environment factors. Spine 1983;8:272-6.

113. Svensson H-O, Andersson GBJ. The relationship of low-back pain, work history, work environment, and stress. Spine 1989;14:517-22.

114. Torell G, Sandén A, Järvholm B. Musculoskeletal disorders in shipyard workers. J Soc Occup Med 1988;38: 109-13.

115. Törner M, Blide G, Eriksson H, Kadefors R, Karlsson R, Petersen I. Musculo-skeletal symptoms as related to working conditions among Swedish professional fishermen. Appl Ergon 1988;19:191-201.

116. Törner M, Blide G, Eriksson H, Kadefors R, Karlsson $\mathbf{R}$, Petersen I. Workload and ergonomics measures in Swedish professional fishing. Appl Ergon 1988;19: 202-12.

117. Vällfors B. Acute, subacute and chronic low back pain: clinical symptoms, absenteeism and working environment. Scand J Rehabil Med 1985;17 Suppl 1:1-97.

118. Videman T, Nurminen T, Tola S, Kuorinka I, Vanharanta $\mathrm{H}$, Troup JDG. Low-back pain in nurses and some loading factors of work. Spine 1984;9:400-4.

119. Videman T, Rauhala H, Asp S, Lindström K, Cedercreutz G, Kämppi, et al. Patient-handling skill, back injuries, and back pain: an inventory study in nursing. Spine 1989;14:148-56.

120. Wickström G, Niskanen T, Riihimäki H. Strain on the back in concrete reinforcement work. Br $\mathrm{J}$ Ind Med 1985;42:233-9.

121. International Organization for Standardization (ISO). Evaluation of human exposure to whole-body vibration: part 1. general requirements. Geneva: ISO,1982. (ISO 2631).

122. Ulfvarson U. Limitations to the use of employee exposure data on air contaminants in epidemiologic studies. Int Arch Occup Environ Health 1983;52:285300.

123. Baty D, Buckle PN, Stubbs DA. Posture recording by direct observation, questionnaire assessment and instrumentation: a comparison based on a recent field study. In: Corlett N, Wilson J, ed. The ergonomics of working postures: London: Taylor and Francis, 1986: 283-92.

124. Burdorf A, Laan J. Comparison of methods for the assessment of postural load on the back. Scand J Work Environ Health 1991;17:425-9.

125. Rossignol M, Baetz J. Task-related risk factors for spinal injury: validation of a self-administered questionnaire on hospital employees. Ergonomics 1987;30: $1531-40$.

126. Corlett EN, Madeley SJ, Manenica I. Posture targetting: a technique for recording working postures. Ergonomics 1979;22:357-66.

127. Holzmann P. ARBAN - a new method for analysis of ergonomic effort. Appl Ergon 1982;13:82-6.

128. Karhu O, Kansi P, Kuorinka I. Correcting working postures in industry: a practical method for analysis. Appl Ergon 1977;8:199-201.

129. Keyserling WM. Postural analysis of the trunk and shoulder in simulated real time. Ergonomics 1986;29: 569-83.

130. Pearcy MJ, Gill JM, Hindle J, Johnson GR. Measurement of human back movements in three dimensions by opto-electronic devices. Clin Biomech 1987;2:199204.

131. Wangenheim M, Samuelson B. Automatic ergonomic work analysis. Appl Ergon 1987;18:9-15.

132. Nordin M, Ortengren R, Andersson GBJ. Measurements of trunk movements during work. Spine 1984; 9:465-9.

133. Snijders CJ, van Riel MPJM, Nordin M. Continuous measurements of spine movements in normal working situations over periods of 8 hours or more. Ergonomics 1987;30:639-53.

134. Punnett L, Keyserling WM. Exposure to ergonomic stressors in the garment industry: application and critique of job-site analysis methods. Ergonomics 1987; 30:1099-116.

Received for publication: 22 July 1991 